\title{
The Effect of Self-Confidence and Subjective Norm On students' Entrepreneurial Intention
}

\author{
Hermin Endratno \\ Universitas Muhammadiyah Purwokerto, Indonesia \\ herminendratno@ump.ac.id
}

\begin{abstract}
The study entitled the effect of selfconfidence and subjective norm on students entrepreneurial intensity in Purwokerto. The study aimed at analyzing the effect of self-confidence and subjective norms to students' entrepreneurial intention. Respondents in this study were university students in Purwokerto. Analyzing tool applied was multiple regression analysis. Based on data analysis, it can be drawn that, self-confidence, and subjective norm presented an effect on students' entrepreneurial intention.
\end{abstract}

Keywords: self-confidence, subjective norm, students' entrepreneurial intention.

\section{INTRODUCTION}

The role of higher educations in motivating its graduates to become a young entrepreneur is very essential in developing number of entrepreneurs. With the growth number of entrepreneurs from higher education graduates, it is expected to reduce the number of unemployed and even increase the number of jobs.

Students' attitudes, behaviors, and knowledge of entrepreneurship will support them to open up new businesses in the future (Indarti and Rostiani, 2008). Kourilsky and Walstad 1998 in Indarti 2008, revealed that the entrepreneurship education is considered as one of the factors that can foster interest and entrepreneurial spirit among the younger generation. [1]

Research on the entrepreneurship intentions is an essential. Since the students' interest in the university is able to be considered as a reference to decide their intention of future entrepreneur or employee.

Ajzen (1991) considered intention as an indication of the degree of effort an individual or group is willing to put up to execute a particular behaviour, thereby, suggesting that it is a behavioural disposition until - the appropriate time and opportunity - an attempt is made to translate the willingness or disposition into action (Ajzen, 2005). [2]

Katz and Gartner (1988) (in Indarti 2008) interpreted that the intentions of entrepreneurship were a process of seeking information that can be used to achieve the goal of creating a business. [1] Thus, someone who has an entrepreneurial intention will have better readiness and progress in the business run than someone who does not have (Indarti and Rostiani, 2008). [1]
Indarti and Rostiani (2008) also discovered that the higher the students' self confidence in their ability to work, the greater their desire to become an entrepreneur. Other studies have proven that entrepreneurial characteristics affected a person's desire to become an entrepreneur (Koh 1996 in Chairy 2011). The entrepreneurial characteristics consist of innovativeness, need for achievement, locus of control, risk taking propensity, and self-confidence. [1], [3]

Sarwoko (2011) in his study discovered that the entrepreneurship factor was positively affected by subjective norms and self-efficacy, the higher students' self-confidence and maturity, the higher the entrepreneurial intention. [4]

Based on the above description, the researcher is interested in conducting a research entitled The Effect of Self Confidence and Subjective Norm on Students' Entrepreneurial Intention in Purwokerto. The difference between this study and previous researches, there was added and changed to its variable and research object. Some of the previous studies presented no correlation to students' entrepreneurial intention or $\mathrm{R}^{2}$ adjusted will be retest. It was expected to escalate the $\mathrm{R}^{2}$ adjusted.

\section{METHODS}

\section{Research Methods}

The research method applied in the research was survey through direct observation to the field. The population was all undergraduate students of public and private universities in Purwokerto. There were some students selected as the sample. The data was analyzed by multiple linear regression analysis. Sampling was conducted through Accidental Sampling method; whoever seen and obtained would be selected as the sample (suitable as data source). (Sugiyono, 2003) [5]

\section{RESULTS}

\section{Respond Rate}

Questionnaires distributed to the respondents are 232 from five universities (STAIN, UNSOED, UNWIKU,UMP,STIMIK AMIKOM) with male 86 and female 146 students. According to distributed questionnaire, there are 86 male respondents $(37,067 \%)$ and 146 female respondent (62,94\%).

\section{Validity Test}

According to data analysis, it is obtained that all Spearman Rho correlation scores of X and $\mathrm{Y}$ variables > 
0.138 (Rho spearman, $\mathrm{df}=(\alpha, \mathrm{n}-2)$ and all significant levels $<=0.05$, therefore it could be concluded that all indicators are valid.

\section{Reliability Test Results}

Table 1. Reliability Test

\begin{tabular}{|c|c|c|c|}
\hline Varia & Alpha & Rho & Conclusio \\
\hline ble & Cronbach's & $\begin{array}{l}\text { Pearson } \\
\text { Correlation }\end{array}$ & $\mathrm{n}$ \\
\hline$X_{1}$ & 0,606 & 0.138 & Reliable \\
\hline$X_{2}$ & 0,700 & 0.138 & Reliable \\
\hline $\mathrm{Y}$ & 0,730 & 0.138 & Reliable \\
\hline
\end{tabular}

The reliable indicator is proven by Alpha Cronbach's score of $\mathrm{X}$ or $\mathrm{Y}$ which is greater than Rho PearsonCorrelation 0.138 (Rho Spearman, $\mathrm{df}=(\alpha, \mathrm{n}-2)$. Based on data analysis, it is known that the score of Alpha Cronbach's of all variables $>0.138$ (Spearman rho table $\mathrm{df}=(\alpha-2)$, it proved that all variables were reliable.

\section{Classic Assumption Test}

a.Normalitas test

With One-Sample Kolmogorov-Smirnov Test , test distribution is normal. Value of unstandardized residual is $0,631(>0,05)$

Table 2. Result of Regression Analysis

\begin{tabular}{crrrr}
\hline Model & $\mathrm{R}$ & R Square & $\begin{array}{c}\text { Adjusted R } \\
\text { Square }\end{array}$ & $\begin{array}{c}\text { Std. Error } \\
\text { of the } \\
\text { Estimate }\end{array}$ \\
\hline 1 &, $429^{\mathrm{a}}$ &, 184 &, 177 &, 62069 \\
\hline
\end{tabular}

a. Predictors: (Constant), average_X1, average_X2

\section{b.Multikolinieritas test}

Value of tolerance and VIF is under 10. So it's good value.

c. Heteroskedastisity test

Using One-Sample Kolmogorov-Smirnov Test, value of unstandardized residual is $0,6319(>0,05)$. It's good value.

All data in this study have passed the classical assumption test.

T Test Analysis

\section{Table 3.Determinant test}

\begin{tabular}{|c|c|c|c|c|c|}
\hline \multicolumn{6}{|c|}{ Coefficients $^{\mathrm{a}}$} \\
\hline \multirow[t]{3}{*}{ Model } & \multirow{2}{*}{\multicolumn{2}{|c|}{$\begin{array}{l}\text { Unstandardized } \\
\text { Coefficients }\end{array}$}} & Standardize & $\mathrm{t}$ & Sig. \\
\hline & & & d Coefficients & & \\
\hline & B & Std. & Beta & & \\
\hline ant) & 1,430 & ,396 & & 3,612 &, 000 \\
\hline $\begin{array}{l}\text { Averag } \\
\mathrm{e} \mathrm{X}_{1}\end{array}$ &, 538 & ,077 &, 416 & 6,965 &, 000 \\
\hline $\mathrm{e} \mathrm{X}^{\text {Averag }}$ &, 101 &, 057 &, 107 & 1,784 &, 076 \\
\hline
\end{tabular}

Table 3 presents that the score of $\mathrm{t}$ count of Self Confidence $(6,965)>\mathrm{t}$ table 1.97 (at $\mathrm{df}=\mathrm{n}-\mathrm{k}$ ) or Sig $0,000<0.05$. Self-confidence is the ability to apply creative solutions to problems.
Self Confidence variables partially have a significant effect on the intention of entrepreneurship. Indarti and Rostiani (2008) also found that the higher the students' self confidence in their ability to work, the greater their desire to become an entrepreneur. [1]

This result is in line with the Endratno's findings (2014) with the respondents of Faculty of Economics students UMP and students of the Faculty of Economics UNSOED stating that Self Confidence partially contributes significant effect on student entrepreneurial intentions. [ 6]

Koh (1996), Nasip (2017), Gelaidan (2017) also found that Self Confidence variables partially have a significant effect on the intention of entrepreneurship. [ 7] [ 8] [ 9]

$\mathrm{T}$ count of Subjective Norm was $1.784<\mathrm{t}$ table 1.97 (at $\mathrm{df}=\mathrm{n}-\mathrm{k}$ ) Sig score $0.076>0.05$. Partially Subjective Norm have no significant effect on the intention of entrepreneurship. This result is different from the findings of Sarwoko (2011), Bhuyan (2012) Tong (2013) Yang, Jianfeng (2013) which discovered that the intentions of entrepreneurship are influenced by subjective norms. [4], [10] [11] [ 12]

The score of determination coefficient Adjusted $\mathrm{R}$ Square is 0.177 or $17.7 \%$ which means that all three independent variables contribute $17.7 \%$ in affecting the dependent variables.

\section{An Analysis of Multiple Linear Regression}

Based on the results of multiple linear regression analysis obtained regression equation as follows:

$\mathrm{Y}=1.430+0,538 \mathrm{X}_{1}+0.101 \mathrm{X}_{2}+\mathrm{e}$

Based on the result, it can be seen:

$\mathrm{Y}=$ student entrepreneur intentions

$\mathrm{a}=1.430$, its constant score means that if there is no change in Self-Confidence and Subjective Norm then the entrepreneurial intention is 1.430

$\mathrm{B}_{1}=0.538$, if the self-confidence increases one percent, the student entrepreneur intentions increase by 0.538 with the assumption that other variables remain the same.

$\mathrm{B} 2=0.101$, if the subjective norm increases one percent, the student entrepreneur intentions will increase by 0.101 , percent with the assumption that other variables remain the same.

\section{F Test}

Table 4. F test

\begin{tabular}{|c|c|c|c|c|c|}
\hline \multicolumn{6}{|l|}{ ANOVA $^{\text {a }}$} \\
\hline Model & $\begin{array}{l}\text { Sum of } \\
\text { Squares }\end{array}$ & df & $\begin{array}{l}\text { Mean } \\
\text { Square }\end{array}$ & $\mathrm{F}$ & Sig. \\
\hline on ${ }^{2}$ Regressi & 19,845 & 2 & 9,923 & 25,756 &, $000^{b}$ \\
\hline Residual & 88,223 & 229 & ,385 & & \\
\hline Total & 108,068 & 231 & & & \\
\hline a. Dependent & Variable: & rerag & & & \\
\hline
\end{tabular}

Based on the results of $\mathrm{f}$ test analysis, $\mathrm{F}$ obtained was 25,756 . This score was bigger than the score of $\mathrm{f}$ table $=$ 2.46. Thus, Self-Confidence and Subjective Norms variables affects to the entrepreneurial intentions. 
Entrepreneurial Intention (Y) is the intention or desire that exists in a person to perform an entrepreneurial action.

Table 5. Respondents answer per-item statement

\begin{tabular}{rlcc}
\hline No & \multicolumn{1}{c}{ Statement } & Average & \multicolumn{1}{c}{ Informati } \\
\hline 1 & $\begin{array}{l}\text { I choose myself as } \\
\text { an entrepreneur. }\end{array}$ & 4.00 & Good \\
2 & $\begin{array}{l}\text { I prefer being an } \\
\text { entrepreneur to an } \\
\text { employee of a } \\
\text { company/organiza } \\
\text { tion. }\end{array}$ & & Good \\
\hline
\end{tabular}

Self Confidence $\left(\mathrm{X}_{1}\right)$ is an ability to implement a creative solution to a problem

\begin{tabular}{rlrc}
\hline No & \multicolumn{1}{c}{ Statement } & Average & Information \\
\hline 1 I am ready for failure & 3.97 & Good \\
2 & I am optimistic about & 4.45 & Good \\
& $\begin{array}{l}\text { business success } \\
\text { I I will have my own } \\
\text { business }\end{array}$ & 4.54 & Good \\
$\quad$ & & \\
\hline
\end{tabular}

Subjective Norm $\left(\mathrm{X}_{2}\right)$ is a social factor which shows social pressure to conduct or not an entrepreneurship.

\begin{tabular}{rlrc}
\hline No & \multicolumn{1}{c}{ Statement } & Average & Information \\
\hline 1 & Family role & 3.78 & Good \\
2 & Support of Important & 4.07 & Good \\
& $\begin{array}{l}\text { People } \\
3\end{array}$ Friends' support & 3.56 & Good \\
\hline
\end{tabular}

Generally, respondents react with "good" answers in all questions and in all variables. It proves that there is an entrepreneurial intention to the respondents.

\section{CONCLUSION}

Based on the results of calculations using multiple linear regression analysis, it can be concluded as follows: Based on $f$ test results, it can be concluded that the variable of self-confidence and subjective norms respectively have a significant effect on students' entrepreneurial intentions. Based on $t$ test result, it is known that self-confidence have partially significant effect to entrepreneurial intention. While the variables of subjective norm partially do not have a significant effect on entrepreneurial intention.

Self-confidence variable is the variable which has the most significant effect on entrepreneurial intentions since it has the biggest score of $t$ obtained.

Suggestions, academic policymakers are encouraged to train and motivate students in improving their selfesteem related to business activities through entrepreneurial subject. It is proven by the most significant effect on student entrepreneurial intentions from the respondent's answer is on the self-confidence variable.

\section{REFERENCES}

[1] Indarti and Rostiani : Entrepreneurship Intention of Students: A Comparative Study Between Indonesia, Japan and Norway in the journal of Economics and Business Vol. 23 Number 42008

[2] Ajzen, I. The theory of planned behavior. Organizational behavior and human decision process, 50(2), 179-211. 1991 . Attitudes, personality and behavior (2nd ed.). London: McGraw-Hill International. 2005

[3] Chairy, The Effect of Entrepreneurial Characteristics, Types of Ethnicity, Gender and The Profession of Parents towards The Entrepreneurship intention of Students in the Journal of Business Management Vol 1 No 2 March, UMY 2011

[4] E. Sarwoko, Empirical Study of Entrepreneurship Intention of Student in the Journal of Business Economics, year. 16, Num. 2, July 2011

[5] Sugiyono, Statistics for research, Alfabeta, Bandung 2003

[6] H.Endratno, Entrepreneurship intention of Students (A Comparative Study Between FE Students of UNSOED and UMP), Proceeding Sustainable Competitive Advantage 4, Purwokerto, UNSOED 2014

[7] Koh, H.C Testing Hypotheses Of Entrepreneurial Characteristics, Journal Of Managerial Psychology vol 111996

[8] S.Nasip, S. R. Amirul, S.L. Sondoh Jr, G. H. Tanakinjal, "Psychological characteristics and entrepreneurial intention: A study among university students in North Borneo, Malaysia", Education + Training, Vol. 59 Issue: 7/8, pp.825-840, 2017

[9] H.M. Gelaidan, A.O. Abdullateef, "Entrepreneurial intentions of business students in Malaysia: The role of self-confidence, educational and relation support", Journal of Small Business and Enterprise Development, Vol. 24 Issue: 1, pp.54-67 2017

[10] M. Bhuyan, $P$. Pathak, Understanding Entrepreneurial Intention Of University Students In Uttarakhand: An Empirical Study : Indian Journal of Commerce \& Management Studies 2012

[11] X.F. Tong,D.Y.K.Tong,L.C.Loy, 2011 Factor Influencing Entreprenuerial Intention Among University Students : International Journal of Social Sciences And Humanity Studies Vol 3, No 1, 2011 Issn: 1309-8063 2011

[12] Yang, Jianfeng, The Theory of Planned Behavior and Prediction of Entrepreneurial Intention Among Chinese Undergraduates : Social Behavior and Personality: an international journal, Volume 41, Number 3, 2013, pp. 367-376(10) 2013 